\title{
Schumpeteryan Girişimcilik ve 21. Yüzyıl Girişimcilik Yaklaşımları: Y Kuşağı Girişimcileri Üzerine Nitel Bir Araştırma
}

\author{
DOI: 10.26466/opus.568703
}

\begin{abstract}
Sabri Öz ${ }^{*}$ - Nazlıcan Dindarik** - Ferdi Duman ${ }^{* * *}$
*Dr. İstanbul Ticaret Üniversitesi, Sanayi Politikaları ve Teknoloji Yönetimi, İstanbul/ Türkiye E-Posta: soz@ticaret.edu.tr ORCID: 0000-0002-6280-726X

**Yüksek Lisans, İstanbul Ticaret Üniversitesi, Lojistik Yönetimi, Beyoğlu/İstanbul/Türkiye E-Posta: nazlcandindarik@gmail.com ORCID: 0000-0003-4313-6576 *** Yüksek Lisans, İstanbul Ticaret Üni., Sanayi Politikaları ve Teknoloji Yön.İstanbul/ Türkiye E-Posta: ferdiduman35@gmail.com ORCID: $\quad \underline{0000-0001-7555-8891}$
\end{abstract}

$\ddot{O} z$

Girişimcilik tarihi çok eskilere dayanmakla birlikte, üretim faktörleri arasında sayılmasının tarihi ayn derinlikte değildir. Özellikle yirminci yüzyılda girişimciliğe ilişkin oldukça yaygin teoremler geliştirilmiş ve üzerine akademik çalışmalar yapılmıştır. Yayg̨n teoremlerden birisi Schumpeter tarafından geliştirilen Schumpeteryan Girişimcilik Teorisidir. Schumpeteryan Girişimcilik Teorisine göre üzerinde durulması gereken asıl konu yenilik ve yaratıcı yıkımdır. Gelişen ve değişen şartlara ne derece uyum sağlandığı ve bu süreçte girişimcilik kavramı ile girişimci özelliklerinin nasıl olması gerektiği ile birlikte bu değ işimin yansımaları ve kuşaklar arası farkllıkarı üzerinde durulmuştur. Bu çalışmada, Schumpeteryan teorisinin geliştirildiği dönem ve anlayışı ile 21. Yüzyılda gerek " $y$ " gerekse de " $z$ " kuşakları tarafindan ortaya konulan girişimcilik anlayışlarında nasıl bir farklılık vardır sorusunun cevabı aranmaktadır. Çalışmaya ilk iki bölümde literatür taraması yapılmış ve üçüncü bölümde girişimciler arasından seçilen üç farklı grup ile mülakat yapılarak ortaya çıkan görüşler doğrultusunda değerlendirilmiştir. Değerlendirme sonucunda elde edilen sonuçlara göre Schumpeteryan girişimcilik teorileri temelde korunur iken, bazı alanlarda dünyanın dönüşümü gereği farklılaştığı görülmüş̧ür.

Anahtar Kelimeler: Girişimcilik, Schumpeter, Girişimcilik Teorisi, Kuşaklar Arası Girişimcilik 


\title{
Schumpeteryan Entrepreneurship And 21st Century Entrepreneurship Approaches: A Qualitative Research on Y Generation Entrepreneurs
}

\begin{abstract}
Although the history of entrepreneurship is very old, the date of being counted among the factors of production is not at the same depth. Especially in the twentieth century, theorems about entrepreneurship have been developed and academic studies have been carried out. One of the common theorems is Schumpeterian Entrepreneurship Theory developed by Schumpeter. According to Schumpeterian Entrepreneurship Theory, the main issue that needs to be emphasized is innovation and creative destruction. The adaptation to the developing and changing conditions and the concept of entrepreneurship and the characteristics of the entrepreneur in this process, reflections of this change and differences between generations are discussed. In this study, the answer to the question of how there is a difference in the concept of entrepreneurship in the 21st century by the generations of $Y$ and $Z$, with the period and understanding of Schumpeterian theory. In the first two chapters, a literature review was performed and in the third section, interviews were made with three different groups. According to the results obtained from the evaluation, while Schumpeterian entrepreneurship theories are basically preserved, it is seen that in some areas the world is differentiated due to transformation.
\end{abstract}

Keywords: Entrepreneurship, Schumpeter, Entrepreneurship Theory, Intergenerational Entrepreneurship 


\section{Giriş}

Araştırmanın çalışma grubunu oluşturan girişimciler yaşları doğrultusunda 3 gruba ayrılarak kuşak farklılıkları incelenmek üzere birinci grup 28 yaş altı, ikinci grup 28 ve 36 yaş arası ve üçüncü grup 36 yaş üstü olarak belirlenmiştir. Girişimcilik yaptıkları alanlara göre iş grupları da incelemeye dahil edilmiştir. Toplamda 20 katılımcı ile yapılan mülakatlar 8 temel soruya verilen cevaplar doğrultusunda şekillenmiştir. Katılımcılardan dördü 28 yaş altı, on biri 28-36 yaş arası, beşi 36 yaş üstüdür.

Araştırmada Shumpeteryan Girişimciliği olarak ifade edilen Girişimcilik teorisinin özellikle yirminci yüzyılın son çeyreğinde doğmuş ve girişimlerini yirmi birinci yüzyılın hemen başında ve sonrasında icra etmiş milenyum girişimcileri arasında nasıl bir ilişki olduğunu ortaya çıkartması açısından önemlidir. Dünya hızla değişimlerin verdiği kısa vadeli büyük dönüşümlere sahne olmaktadır. Doksanlı yıllarda cep telefonu yok iken, milenyumda dört yaşında çocukların ekran bağımlılığına çözüm bulmaya çalışan bir dönüşümden bahsedilmektedir. Sendikaların etkinliği tartışılırken, yapay zekanın, makinelerin eğitiminden ve bir anda karanlık fabrikalardan ve insansız topraksız tarımdan söz edilir hale gelinmiştir. Daha da futuristik yaklaşımların beklendiği farklı literatürlerde ifade edilmektedir. Sentetik biyoloji insansı robotlar ve endüstri devriminde X.0 anlayışları çok uzak değildir.

Bütün bu gelişimler ve dönüşümler içinde her türlü teoremler ve iddialar da değişime uğramakta ve geçerliliğini ya kaybetmekte ya da revize edilmektedir. Son yüzyılın son çeyreğine gelinmeden ortaya atılan teoremlerde ciddi farklılıklar söz konusudur. Schumpeter Girişimcilik teorisi de Drucker'ın görüşleri ile bir başka yön bulmuş olmakla birlikte, yeni dönemde çok daha farklı bir rotaya gireceği söylenmektedir. Rotanın eksen kaymasına yol açması ile teorinin çürüyeceği ifade edilebilecek iken, bu çalışma Schumpeter yaklaşımının henüz geçerliliğini koruduğu alanlara sahip olduğunun bir göstergesidir.

\section{Schumpeter Girişimcilik}

Girişimcilik kavramı geçmişten günümüze kadar başta işletme ve iktisat bilimi olmak üzere birçok farklı bilimde yıllardan beri kullanılmaktadır. 
Girişimci üretim faktörlerini bir araya getirmek suretiyle insan ihtiyaçlarını karşılamak üzere iktisadi mal ve hizmet üretiminin gerçekleştirilmesini sağlayan kişidir (Karalar, 2001, s.13).

Girişimciliğin bir süreç olduğu ve bazı fikirlerin bulunmasıyle birlikte bunların gerçeğe dönüştürülerek ürün haline gelmesi, bu ürünlerin veya hizmetlerin piyasaya sunularak girişim hareketinin kurulmasını kapsamaktadır. Başka bir girişimcilik tanımı ise girişimciliği; “bir birey veya birey grubunun; hangi kaynaklar elde bulundurulursa bulundurulsun, değer ve büyüme yaratmak için eşsiz, tek olma ve inovasyon yoluyla, gereksinimleri yerine getirecek firsatları izlemek üzere düzenlenmiş güç ve imkanları kullandıkları süreç" olarak belirtir (Coulter ve Robbins, 2003, s.42).

Girişimcinin kim olduğu önem teşkil etmekle birlikte, bir kasap, tesisatçı, holding sahibi ya da perakendecinin de iş fikrine ve bu iş fikrini gerçeğe dönüştürebilme yetisine sahip olup risk alabildiği sürece girişimci olacağı sonucuna varılır. Burada önemli olan kimsenin göremediği, aklına getirmediği bir düşünceye sahip olmak ve bu fikri koruyarak, cesaret edip bunu iş fırsatı olarak kullanabilmektir (Durukan, 2006, s.29).

Joseph Alois Schumpeter'e göre modern bir girişimcinin tanımı "Girişimci ekonomik gelişmenin altında yatan güçtür (Santarelli ve Vivarelli, 2007). Aynı zamanda toplumda değişimi yaratacak kişi ve kurumlardır (Müftüoğlu, Ürper, Başar, ve Tosunoğlu, 2005, s.4)."

Schumpeter, girişimci olmanın temelinde yenilik, yaratıcılık ve değişim yaratmanın önemini vurgulayarak girişimcinin yalnızca yenilik faaliyetleri yaparak bu faaliyetleriyle mevcut kaynakların birleşimindeki bir yenilikten bahsetmektedir (Odabaşı, 2005, s.91).

Yenilik ve girişimcilik kavramlarına yeni bir bakış açısı getiren Schumpeter ekonomik kalkınmayı sağlayacak analizler üzerinde durmuş ve kapitalist sistemle ilgili kitabında da belirttiği üzere bu konu üzerinde yaklaşımlarını anlatmıştır.

Bu görüşüyle Schumpeter, girişimciyi sıradan bir kapitalist olarak görmediği gibi tam tersi, değişimler yaratan ve yol açan, sanayi toplumundan bilgi toplumuna geçişte yeniliğin önemini vurgulayan, üretim aşamasında yeniliklerle olağan seyrin değişmesini sağlayan kişidir. Girişimci bu yeniliklerin niteliği ne olursa olsun ister çevresel, ister 
teknolojik her türlü yatırım durumunu fırsata çevirir (Dolgun, 2006, s.174).

Schumpeter girişimcilikte yenilik ön planda yer alarak yaratıcı yıkıma neden olmakta ve dengesizlikler üzerinde denge faktörü olarak ekonomik değişimi sağlayan yenilikleri ve yeni birleşimleri ortaya çıkarmaktadır (Basilgan, 2011, s.27).

Schumpeter'in The Theory of Economic Development (1934) adlı çalışmasında kapitalizm sürecinde girişimci kurmaya çalıştığ 1 yeni ekonomik teoride yeni kombinasyonların yapılmasına "girişim" adını verirken onu işlevsel hale getirerek fonksiyonun yapacak kişiye ise "girişimci olarak adlandırmıştır (Hebert ve Link, 1989, s.44).

Schumpeter girişimcilik işlevini yeni bir malın ya da daha iyi kalitedeki bir malın tanıtılması, bu yeni mallar için yeni bir piyasanın açılması, yeni üretim metodunun tanıtılması, hammadde veya yarı mamul tedariki için yeni kaynakların bulunması, sektör fark etmeksizin yeni bir organizasyonun yürütülmesi olarak tanımlamıştır (Sciascia ve Vita, 2004, s.146).

Girişimcilik kavramı ne kadar geçmişe dayansa da ana amaç kar elde etmek ve iktisat teorisine uygun olarak hareket etmek iken Schumpeter iktisadın, ekonomik modelde girişimciyi dışarda tutmasına neden olan faktörleri yıkarak yaratıcı yıkım sürecinin temel taşı olarak girişimciği ve onun getirdiği yenilik anlayışına sahip geniş vizyonu ileri sürmüştür.

Schumpeter girişimciyi dinamik bir unsur olarak gördüğü için sermaye sağlamaktan daha gelişmiş olarak inovasyon-yenilik yapan sürekli bir ilerleme sağlayan yaratıcı yıkım sürecinin en önemli parçası olarak görüyordu. Bu durumu iktisat teorisinde Marx Weber'in görüşüne yakın bir konumda durarak ancak onun bazı savlarının tersine kapitalist sistemin yıkılmasınının sistemin başarılarının sonucunda ortaya çıkan bir eseri olacağını şu sözleriyle belirtti:

"Eğer bir doktor hastasının öleceğini tahmin ediyorsa bu, doktorun hastasının ölmesini arzu ettiği anlamına gelmez (Ülgener, 2013)."

Buradan hareketli eski girişimcilik yargılarından; yani sadece riski göze alan, cesaret sahibi olan girişimcilerin yerine sürekli gelişim ve değişim içerisinde olarak yenilikle desteklenen, kendisini yenilikle yenileyen bir anlayış hakim olmakta küreselleşen dünyada rakiplerinden 
ayırt edilmeyi sağlayan en önemli güç olarak yenilikçi girişimcilik kavramı gelmektedir (Er, 2013, s.76).

\subsection{Schumpeter Girişimcilerin Bireysel Özellikleri}

Schumpeter girişimci nitelikleri bağlamında sıradan kapitalistlerle aynıymış gibi görülmemelidir. Çünkü bu girişimciler yalnızca kar etme amacı gütmemekte; bunun dışında firsatları değerlendirmek üzere yenilik arayışı içinde olan, piyasadaki durumdan haberdar olarak oluşabilecek riskleri elimine ederek uyanık ve cesaret sahibi olan kişidir (Dolgun, 2006, s.175).

Schumpeter'e göre bireyler güdüleri doğrultusunda hareket etmekte yani alışılagelmiş faaliyetlerin ve uyarıcıların yer aldığı bir dünyada iş yapmaktadır. Benzer durumlarda benzer tepkiler vermektedir. Bunun sonucunda bireyler dürtüleri, gelenek ve görenekleri ölçüsünde ekonomik faaliyetlerin büyük bir oranı hatta daha büyük birçoğu bu temel üzerinedir (Schumpeter ve Takata, 1998, s.8).

Birey duruma uyum sağlayan bir yapıya sahip olduğu için güdülerine ve dürtülerine göre hareket eder. Bunun sonucunda değişen yeni duruma göre davrandığında çevresi onu şekillendirir ve ona göre kararlar verir.

Schumpeter bireyin tecrübeleri sonucunda günlük yaşama dair kararlar aldığını ve bu kararların bireysel aklın küçük bir alanı içinde uzandığını ve burada genellikle bireyin kendisini, aile üyelerini, iş durumu ve orada kurduğu ilişkileri ile alakalı olan, kişinin kendi gözlemlerinden meydana gelen, tanıdık şeylerden oluştuğunu belirtmiştir (Schumpeter, 1942, s.258).

Girişimcinin, değişimin harekete geçiriçi gücü olması gerektiğini söyleyen Schumpeter, standart ve belirli kalıpların dışına çıabilen benzersiz bireylerde bunun mümkün olduğunu belirtmiştir. Bu bireylerin riski iyi yönetebilmeleri, net olmayan durumlarla baş edebilmeleri gerekmektedir. Değişime ve yeniliğe ulaşmak için irade gücü ve sosyal çevre tarafından eleştirilere ya da komik duruma düşme gibi şeylere karşı dirençli olması gerekliliğinden bahsetmektedir (Whelan ve O'Gorman, 2007, s.82).

Yenilikçi-Girişimci ekonomik değişimin kendisine sebep olan ana etmen durumunda olduğunda ekonomik değişimi kolaylaştırmaktan öte 
değişimin nedeni kendisi olacaktır. Bu değişime neden olma isteği girişimcide kazanma arzusu, yenilik ve yaratma zevki, kendi krallığına sahip olma ihtiyacı onu kamçlayacak, yeni bir seviyeye getirecektir (Kalantaridis, 2004, s.489).

Schumpeter'e göre girişimciliğin değişmeyen özelliklerinden birisi sosyal lider olarak girişimcinin rolüdür. Sosyal liderliği karar verme, emretme, üstün gelme ve ilerleme olarak görmüştür. Girişimcinin en önemli yeteneklerinden olan liderlik niteliği sosyal ve psikolojik baskıların üstesinden gelip direnç gösterebilmesidir. Bunun dışında Schumpeter denince akla ilk gelen ve çok bilinen yenilikçi girişimci ve yaratıcı yıkım kavramlarıdır. Neoklasik iktisat değişimine ve burada dengesizliğe neden olan yenilikçi girişimci kavramıla yaratıcı yıkım teorisiyle desteklemektedir (Basilgan, 2011, s.38).

\subsection{Schumpeter'de Yenilik Kavramı ve Girişimci}

Schumpeter The Theory of Economic Development ve Capitalism, Socialism and Democracy ve Business Cycles adlı çalışmalarında yeniliğin öneminden bahsetmiş ve ekonomik sistemde değişimi ve gelişimi sağlayacak unsurun girişimci aracılığıyla olan yenilik olarak değerlendirmiştir.

Yenilik için yapılan tanımlamalarda Drucker'a (1998) göre "yeni ve değişik bir şey yapmak" Akyos'a göre ise "düşünce geliştirme, teknoloji geliştirme yeni veya geliştirilmiş ürün veya üretim yöntemi veya ekipmanı üretme ve pazarlama faaliyetlerinin yönetimidir (Akyos, 2004)."

Schumpeter ise girişimcilik faaliyetlerini ve yeniliklerin teknolojik boyutunu durağan ekonominin üretken kaynaklarını sürekli değişikliklere ve yeniliklere geçiren güç olarak ele alır (Er, 2013, s.76). Ekonomide değişimler yani dalgalanmalar yeniliğin etkisiyle ve bu etkiye ekonominin uyum sağlamaya çalışması sürecinde oluşan değişimlerdir (Savaş, 2007, s. 834). Sürecin sonunda yeni bir ürünün ortaya çıkması üç aşamadan oluşur; icat, yenilik ve yayılma (Taymaz, 2001, s.3).

Schumpeter' in çalışmalarından da anlaşılacağı üzere iktisadi devreleri dört aşamaya ayırmıştır; refah, durgunluk, bunalım ve canlanma olarak incelemiştir (Aydoğmuş, Türkcan, Tunali, ve Kopurlu, 2009, s.13).

Schumpeter' in yenilik ve büyüme ölçütü yaratıcı yıkımla birlikte gelen yenilik hareketidir. Rekabeti sağlayan yenilik ise piyasada yaratıcı 
tepkiler verebilmek, monopolistik rekabet, yapı-yönetim-performans sağlamak, baskın tasarım ve ağ dışsallıklarıdır. Bilgiyi de kullanarak yenilik fırtınası estirmek, araştırma geliştirme faaliyetleri yaptırmak, teknoloji itmeli ve teknolojik fırsatları fark ederek gelişen sistem içerisinde yenilik sağlamaktır. Sektörel modelde dinamik etkinlik sağlayarak yaratıcılığı ön plana çıkarmak genel amaçlı teknolojilerde teknolojik rejimi benimsemektir (Antonelli, 2009, s.613).

Yaratıcı yıkım kavramı ise önceden var olan bir piyasanın yenilik yapan bir piyasa karşısında yok olmasını ya da önemli bir oranda daralmasını ve yeni büyüyen piyasanın farklı firmaları da içine alarak genişlemesine denir (Chen ve Chen, 2001, s.2). Bu süreç asla bitmeyen ve devamlı yenilenen bir sürekliliktir. Örnek olarak ampulün icat edilmesiyle, gaz lambalarının artık kullanılmaması ve o piyasanın silinmesi verilebilir (İraz, 2005, s.83).

Yaratıcı yıkımda esas olan ürünlerin ve süreçlerin inovasyonudur. Eski ürün ve süreçlerin yerini yenileri alır ve bu durum ekonomik sistemi etkilediğinde sistemde oluşan sorunun çöküşe neden olmasıyla yapısal bir soruna dönüşür. Çünkü inovasyon paradigma değişiminin çekirdeğinden oluşur (Tiryakioğlu, 2009).

Shumpter'in çokça üzerinde durduğu yaratıcı yıkımı gerçekleştirecek olan girişimcinin iktisadi sistemin içerisinde içsel değişimi gerçekleştireceğini ve onun metedolojik bireyciliğiyle uyumlu olduğunu vurgulamaktadır. Geçen zaman içerisinde diğer bireylerden farklı niteliklere sahip olan girişimci ekonomik yenilenmeyi sağlamakta ve bunu yaparken bilimsel araştırma yöntemlerini kullanarak, sezgi, kavrama yeteneği, liderlik, eleştirel akıl ve irade gibi özelliklerine de güvenmektedir (Schumpeter, 1961, s.87).

Schumpeter'e göre dinamik girişimci; yaratıcı yıkım yaşayan yani her zaman yenilik arayışı içerisinde olan, eski yöntemleri bırakarak yeni yöntemleri devreye sokan, temin ve tedarik kaynaklarını genişleten, yeni organizasyon ve süreçleri uygulayan, ekonomik değişimin ve büyümenin yapı taşı olarak tanımlamıştır (Müftüoğlu ve Durukan, 2004, s.42).

Girişimcilerin ekonomik gelişmeyi sağlamak için liberal kapitalist sistem içinde dinamik bir aktör olarak yer almaları, araştırmalar , buluşlar ve icatlar yaparak üretime yenilik getirmeleri gerekmektedir. Schumpeter'in iktisat teorisine göre bu şekilde davranmayan 
girişimcilerde ve onların yaşadığı toplumlarda rekabet yoğunlaşacak, kar oranı azalacak ve faiz hadleri çok düşük seviyelere inecektir. Tam tersi olan toplumlarda dinamik girişimciler daima yenilik arayışında oldukları için üretim hacmi ile orantılı olarak kar oranı artacak, rekabet sürekli olarak artacak ve fiyatlar da düşecektir. Tüm bunların getirisi olarakta işçiler ve tüketiciler fayda görecek, toplumun seviyesi ilerleyecek, ekonomik refah ortaya çıkacaktır. Bu gelişmelere ayak uyduramayan, ticari gelişme gösteremeyen firmaların ortadan kalkması ile ekonomik üretim kapasitesinde sürekli bir genişleme oluşacaktır (Dolgun, 2006, s.174).

Schumpeter yenilik ve yaratıcı yıkım hakkındaki düşüncelerini;

“...kapitalist mekanizmayı çalıştıran ve çalışmasını devam ettiren; yeni tüketim maddeleri, yeni üretim metotları, yeni ulaşım metotları, yeni pazarlar, yeni endüstriyel örgütlenme tipleri, çeşitleridir ve bütün bunlar kapitalist teşebbüs tarafından yaratılmışlardır. Yeni milli pazarların veya dış piyasaların açılması; el sanatları atölyelerinden, yoğun ve büyük işletmelere geçiş, kapitalist sistemi durmadan, yorulmadan içinden bir ihtilal, yenilenme havasında tutmakta; bütün bu elemanlar gene devaml olarak eski faktörleri yok etmekte, yenilerini yaratmaktadır. Bu 'Yaratıcı Yıkım Gelişimi' kapitalizmin esas temeldir; ister istemez her kapitalist teşebbüs er geç bu gelişime ayak uydurmak zorundadır..." sözleriyle belirtmiştir (Schumpeter, 1942).

\section{21. Yüzyıl'da Girişimcilik}

21. yüzyılda yaşadığımız değişim ve gelişim ortamından en çok etkilenen kavramların başında şüphesiz girişimcilik gelmektedir. Girişimcilik geçmişten günümüze kadar evrilmiş ve birçok farklı süreçten geçmiştir. Geçmişte her ne kadar fırsatları hızla görüp, risk alan cesaretli kişiler girişimci olurken günümüzde daha 1lımlı bir şekilde gözlem yapıp, bilgiyi kullanarak akılcı kararlar alan, yaratıcılığını harekete geçiren kişiler girişimci olmaktadır.

Bilgi çağına geçiş olarak değerlendirdiğimiz bu dönemde kültür değişimi ve liderlik kavramının algılanmasındaki değişim tüm toplumları ilgilendirmektedir. İnsan artık bilgi çağının merkezinde yer almakla birlikte ekonomik ve sosyal yapının da merkezindedir. Bu yapının içerisinde girişimci piyasayı yakından takip eden boşlukları görüp 
değerlendiren kişidir. Girişimcinin ihtiyacı olan bilgi ve bunu yönetebilme kapasitesine sahip olmaktır (Yeniçeri, 2002, s.57).

Bilgi toplumu sanayi toplumunun aksine daha çok bireyselliği, ademi merkeziyetçiliği, kültürel açıdan yerelleşmeyi ve mistik eğilimleri içerirken sanayi toplumu bireysellikten ziyade standartlaşmayı, kitleselleşmeyi savunuyordu (Tekin ve Çiçek, 2005).

Değişimin ve yeniden yapılanmanın sonuçların gösteren etmenlerin ve bunu zorunlu kılan nedenlerin başında küreselleşme, ulusallaşma ve kurumsallaşma gelmektedir (Odabaşı, 2005, s.89).

Günümüzde yaşanan rekabet ortamında girişimcilerin başarıya ulaşmasında yenilik, yaratıcılık ve değişim ön plana çıkmaktadır. Talep edenlerin istek ve ihtiyaçları, beklentileri, tüketim algıları ve bununla birlikte üretim sistemleri de gelişen teknolojiyle ve yenilik hareketiyle değişime uğramaktadır. $\mathrm{Bu}$ değişime ayak uydurabilen inovatif girişimciler, inovatif ürün ve hizmetler yaparak varlıklarını devam ettirebileceklerdir (Alkan, 2014, s.3).

Girişimciliğin yaygın olduğu ve teşviklerin yapıldığı ülkelerde işsizlik oranı azalarak yapılan yatırımların oranı artmaktadır. Verilen destekler arttığında sosyo-ekonomik parametrelerde bunların yansımaları net bir şekilde görülmektedir (Coulter ve Robbins, 2003, s.144). Toplumda görülen refah seviyesinin de yükselmesiyle girişimciliğin ekonomik ve sosyal değişimi etkileyen önemli faktörlerden biri olduğu anlaşılmaktadır.

Sosyal ve ekonomik gelişmeyi sağlamak, ülkede yaşayan insanlar ve yaşadıkları bölgeler arasında dengesizliği azaltarak kalkınma düzeyini arttırmada en önemli rol girişimcilere düşmektedir. Özellikle gelişmekte olan ülkelerde bu çalışmalar yapılarak girişimcilerin niteliğinin arttırılması, sivil toplum kuruluşlarının, devletin, üniversitelerin ve benzer kuruluşların destekleri önem teşkil etmektedir. Bu süreçlerin doğru ve başarılı bir şekilde yönetilmesi girişimcilik faaliyetleri ve niteliklerini geliştirmekle birlikte ekonomik büyümeyi, istihdamın artmasını ve kalkınmayı sağlayacaktır (Perktaş, 2014, s.472).

Girişimciliğin en çok etkilediği alanlardan biri ekonomik yapıya olan etkileridir. Burada en önemli destek devlet tarafından beklenmektedir. Çünkü devletin yarattığı tam rekabetçi pazar ortamında devlet bazı piyasalardaki pazarlarda geride durarak girişimcinin buralara girmesine 
uygun ortamı hazırlamalıdır. Girişimcilik arttı̆̆ müddetçe iş olanakları ile ilgili olarak kamuda yığılma azalacak ve insanlar farklı iş fırsatlarından yararlanarak yön değiştirecektir. Gelir dağılımı daha orantılı bir seyir izleyecektir. Dengeli bir dağılımın oluşmasıyla ekonomik kalkınma ve bağıntılarıyla bu durumdan etkilenen teknolojik gelişmeler de olucaktır. Tekelcilik durumuyla ilgili karşıt bir durum ortaya çımış olur. Daha esnek bir endüstri oluştuğu için üretim ve sanayileşme yaygınlaşır (Kuvan, 2007, s.79). Kısacası girişimcilik birçok yeniliği teşvik ederek değişimin ve dönüşümün önünü açar.

Girişimciliğin ekonomik yapıya olduğu kadar sosyal yapıya etkileri de vardır. Girişimciler yaptıkları yeniliklerle insanların hayatını kolaylaştırarak, refah seviyesi arttırırlar. Bu sayede insanlar istek ve ihtiyaçlarına kavuşarak haz almakta ve daha rahat bir hayat sürerek mali durumlarını iyileştirebilmektedir. Çevresel bilincin gelişmesine de katkı sağlayan girişimciler teknolojiyle harmanlayarak yenilikçi ürün ve hizmetlere dönüşümü hızlandırmaktadır. Dinamizmin oluşmasına katkı sağlayarak insanların yaşam kalitesini arttırıcı her türlü eylemde bulunmaktadırlar (Bozkurt ve diğerleri, 2012, s.233).

Üretim faktörleri arasında yer alan girişimcilik fikri olan emeğin ekonomik bir değere dönüşmesi olarak açıklanabilir. Ekonominin büyüyebilmesi için öncül şartlardan bir olan girişimciliğin yeni düşüncelerin hayata geçirilmesi ve yeni kurulacak firmaların bu mantaliteyle hareket etmesi gerekliliğidir. Buradan hareketle girişimcilerin ve işletmelerin sayısının arttırılması ve bunların eğitilmesi kalkınmayı sağlayacaği için hedeflenmelidir (Başar ve Tosunoğlu, 2006, s.124).

Girişimcilik faaliyeti farklı türler içerse de her piyasada ve pazarda ayrı ayrı desteklerin sağlanması gerekmektedir. Girişimcilik türleri arasında fırsat girişimciliği, yaratıcı girişimcilik, takipçi girişimcilik, sanal girişimcilik, çevreci girişimcilik, sosyal girişimcilik, iç girişimcilik, kurumsal ve kamu girişimciliği sayılabilir (Alkan, 2014).

Son yıllarda en çok karşımıza çıkan girişimcilik türlerinden olan internet girişimciliği yani sanal girişimcilikte teknoloji ve ekonomideki hızlı değişim ve yeni olanakların sunulmasıyla talebi değiştirmiş, istek ve ihtiyaçlar farklılık göstermiştir. Kuşakların demografik özellikleri 
incelendiğinde girişimlerin hangi boyutta değiştiği de ortaya çıkmaktadır (Yelkikalan, Akatay, ve Altın, 2010, s.491).

\subsection{Yüzyıl'da Girişimcilerin Bireysel Özellikleri}

Başarılı girişimcilerde bulunması gereken belli başlı özellikler vardır. Psikolojik, davranışsal vb. kuramlar olsa da genel anlamda değerlendirdiğimiz zaman bazı ortak özelliklere ulaşılabilir.

Bilgi toplumunda yer alan girişimciler dünyaya farklı bir gözle bakarak fark edilmeyeni fark ederler, çevresel unsurları kullanmayı iyi bildiklerinden dolayı iletişimi ve sembolleri yerinde kullanırlar. Geleceği iyi tanıyarak ona yön verirler. Talepte oluşan değişimlere karşı esnek ve uyumlu oldukları için farkındalıkları yüksektir. Kıt kaynakları doğru kullanıp israf etmezler. Her konuda çeşitliğin olmasında yana oldukları için kültürel, sosyal, zihinsel farklılıkları iyi analiz ederler (Gül, 2005).

Girişimcileri girişimci yapan ilk aşama fırsatları görüp değerlendirmeleri ve bunu risk alma cesareti göstererek yapmalarıdır. Küçük bir işletmeyi katma değer yaratarak yönetmek ve geliştirme istekleri içerisinde olmalarıdır. Girişimci yaratmış olduğu istihdamı devam ettirerek, yaptıklarının sorumluğunu almalıdır. Değişimi yönlendirerek, rekabeti yaşam şekli yaparak, işletmesinin gelişmesini sağlayacak ve öne çıkmasına neden olacaktır. Yapmış olduğu yenilikleri topluma yansıtması sonucunda ulusal refahı ve kalkınmayı sağlayacaktır. Bunları yapmasını sağlayan yegane gücü de istikrarlı, kararlı ve azimli olmasidir (Akpinar, 2009).

Girişimciler ne kadar başarısız olsalar da vazgeçmezler ve yeniden denerler. Detaylara önem vererek en iyisini isterler. Sonuçlar belli olmasa da tolerans gösterebilme yeteneğine sahiptirler. İstek ve kabiliyetlerinin bilincinde olarak riskleri üstlenirler, aldıkları risklerin sonuçlarına göre ders çıkararak yollarına devam ederler. Enerjileri ve azimleri yüksek, problem çözme potansiyelleri gelişmiştir (Arıkan, 2002, s.29).

Mantık çerçevesi içerisinde olan riskleri göze alan ve gereksiz riske girmeyen, kararlı olan, ne yaptığını bilen, başladığı işi sonuna kadar götürüp bitiren, çok yönlülüğünü kullanarak eksikliklerini de görebilen, kendine güvenen, taviz vermeden her şeyin doğru ve zamanında 
yapılmasını planlayan, değişikliklere adapte olup uyum sağlayan kişilerdir (Bozgeyik, 2005; Durukan, 2006; Müftüoğlu, 2004; Titiz, 1994).

Girişimcilik için gerekli olan beceri türlerini teknik, yönetsel ve bireysel beceriler olarak üç ayrı sınıfta inceleyebiliriz. Teknik becerilerde girişimcilerin sözlü iletişiminin kuvvetli olması gerektiğinden bahsetmektedir. Teknik yönetim bilgisi ve uygulama şekli önem teşkil etmektedir. İyi bir dinleyici olup toplumu örgütleme konusunda becerili olması, şebeke kurabilmesi, takım oyuncusu olup, ustalık yaparak yetiştiricilik özelliklerine de sahip olması sayılabilir. Yönetsel becerilerde de amaçlarını doğru belirleyip karar vermesi, insan ilişkilerini iyi yönetmesi gereklidir. Pazarlama, finans, muhasebe, yönetim, denetim alanlarında bilgi sahibi olmalıdır. Sorun çözerek, yönetim geliştirdiği sürece yönetsel becerilere de sahip demektir. Bireysel beceriler ise içsel denetimi sağlayarak kontrollü ve mantıklı olması, yenilik yaparak, değişimi yönetmelidir. Vizyon sahibi olarak önünü görmesi yol gösterici olacaktır (Hisrich ve Peters, 1998, s.20).

Girişimcilerin asıl amaçları yeni ürünleri keşfetmek ya da işlevinde bazı değişiklere yol açmaktır. Üretim yöntemlerinde farklılık yaratarak geliştirmek ve uyarlamak, sanayi de gelişmiş yöntemleri uygulayarak yeni pazarlara açılmayı hedeflerler. Yönetim ve çalışanlar arasındaki ilişkileri geliştirmeye özen gösterirler (Karalar ve diğerleri, 2006, s. 14).

\subsection{Girişimciliğin Gelişim Süreci}

Girişimcilik çok eski tarihlerden bu yana var olan bir kavram olmasına rağmen son zamanlarda daha fazla irdelenmekte ve akademik açıdan araştırmaya konu olmaktadır. Girişimcilik hakkında her çağda farklı görüşler hâkim olmuştur. Bunu destekleyen farklı düşüncelere sahip olan bilim adamlarıyla birlikte görüşlerde farklılık göstermiştir.

İlk çağlarda girişimciler hayatını idame ettirmek için arayış içerisinde olan özgür kişiler olarak görülmekteydi. Orta çağda risk unsuru ortada yoktur ama büyük ölçekli üretim projelerinin yöneticisi olarak girişimci vardır. 17. yüzyılda devletle yaptığı sözleşmelerde sonuçlara katlanan yani kar veya zararı üstlenen kişi konumundadır. 18. yüzyılda farklı bilim adamlarının düşüncelerine göre girişimcilik ile ilgili farklı görüşler bulunmaktadır. Say'a göre girişimcinin elde ettiği kazanç, sermayeninkinden 
ayrılmıştır. Walker ise fon sağlayıcı ile projenin sahibi olan girişimcinin kazançlarının ayrıldığından bahsetmiştir. 1934'lere gelindiğinde Schumpeter girişimciyi yenilik yapan ve yeniliğe uygun teknolojiler geliştiren kişi olarak tanımlamıştır. 1961 yılında McClelland faal olan, 1lımlı, riskleri üzerine alan kişi olarak girişimciden bahsetmiştir. 1964 yılında gurulardan biri olan Peter Drucker, girişimciyi fırsatları en üst düzeye çıkarıp onlardan yararlanan kişi diye nitelendirmiştir. Vesper her kesimin girişimciyi farklı algıladığını bir ekonomistin, psikoloğun ya da iş adamının değerlendirmesinde değişiklikler olduğunu gözler önüne sermiştir. Hisrich 1985 yılına gelindiğinde girişimciyi detaylandırarak zaman ve emek harcayarak farklı değerler ortaya çıkaran, çeşitli riskleri alan, sonunda maddi ya da manevi getiri sağlayan kişi olarak tanımlamıştır. Son yüzyıllarda ise Busenitze'ye göre girişimci ekonomik refahın ortaya çıkmasında en büyük rol oynayan kişi diyerek açılamıştır (Çelik, 2006; Hisrich ve Peters, 1998; Timmons, 1999).

İnsanlığın var olduğu zamandan günümüze kadar rol almış olan girişimcilik kavramı insanlığın gelişmesinde etkili olan bir olgudur. İlk çağlardan bu zamana kadar yaşamak ve ihtiyaçlarını karşılamak amacıyla insanlar avcllık, hayvancılık, ticaret gibi birçok faaliyette bulunmuş ve daima girişimciliği bir yerlerde barındırmıştır. Şimdiki gelişmiş teknolojiye, modern üretim ve yönetim tekniklerine ulaşllana kadar birçok değişim ve gelişim gözlenmiştir. Bu değişimlerin başında bilgiye dayalı düşünen yenilikçi anlayışa sahip girişimciler gelmektedir (Aşkın, Nehir, ve Vural, 2011, s.57).

Çağdaş girişimciliğin gelişim süreci 15-16. yy'da coğrafi keşifler ile başlamış, bu süreçte altın ve para ön plana çıkmıştır. Aynı zamanda modern bilim metodolojisi gelişim göstermiş, rönesans ve reform hareketleri oluşmuştur. Bu hareketler beraberinde bilimsel bilgiyi getirmiştir. 18. yy'da buhar makinesinin icadı teknolojik gelişmeleri gündeme getirdiğinde yine 18-19. yy'da sanayi devrimi gerçekleşmiş ve artık serbest piyasa girişimcisi kavramı ortaya çıkmıştır (Özakpınar, 1999, s.88).

İnsanlar ilkel toplumlarda tarıma dayalı olan ev ekonomisiyle geçimlerini sağlarlarken tarıma dayalı ev ekonomisine geçildiği dönemlerde derebeylikler kurulmuştur. Avcılık ve toplayıcılıktan yerleşik bir hayata geçildiğinde sosyal ve ekonomik yönden gelişmeler ortaya çıkmıştır. Bu dönemde bireysel girişimcilikten ziyade takas ekonomisi 
görülmektedir. Daha sonra tarım faaliyetlerinden uzaklaşılıp küçük el sanatlarına dayanan kent ekonomisine geçilmiştir. Ekonomik faaliyetlerin temelinde kentler, endüstri ve ticaret yer almaktadır. İmal edenler ve köylüler arasında alım satım faaliyetleri görülmektedir ve ilerleyen süreçte üreticilerle zanaatkarlar arasında da bu gibi faaliyetler yapılmaya başlanmıştır. El sanatlarının artmasıyla birlikte meslek çeşitliliği de artmıştır (Vural, 2006, s.42).

İzleyen zamanlarda 12-13. yy'da fuarların kurulmasıla birlikte pazarlar gelişmeye başlamış ve sadece ulusal değil uluslararası anlamda gelişmeler görülmüştür. Mesleki rejimler ön plana çıkarak özgür bir şekilde seçim şansı tanınmıştır. 13-14. yüzyıllarda büyük sermayederlerin ortaya çıkmasıyla birlikte özel bankalar açılmaya başlamıştır. 15 ve 19 . yüzyıllar arasında Avrupa'da bazı iktisadi düşünceler ortaya çıkmış ve girişimciliğin gelişimini etkilemiştir (Aşkın ve diğerleri, 2011, s.57). Bunların içerisinde;

Merkantalizm: Devlet idaresine dayanan ve ekonominin büyümesini sağlayan bir araçtır.

Fizyokrasi: "Bırakınız yapsınlar, bırakınız geçsinler" sloganıyla serbestiden yana olan tarımsal üreticiyi ön plana çıkaran iktisadi bir görüştür (Vural, 2006).

Klasik Iktisat: Bireye ve bireysel girişimciliğe önem vererek devleti bireyin faaliyetlerini sınırlayıcı olarak gördüğü için görevleri bireysel olarak üstlenmeyi kabul eden bir görüştür.

20. yüzyılda girişimci birey tipinin nitelikleri değişmeye başladı. Bu değişim beraberinde ekonomik ve toplumsal değişime ve değerlerin farklı algılanmasına neden oldu. Girişimcilik artık üretim faktörü olarak algılanmaya başladı. Şirketin sahibi ile yönetim pozisyonu birbirinden ayrıldı ğında girişimcilikte farklı bir şekilde ekonomide yer almaya başladı (Küçük, 2005, s.32).

Refah devlet uygulaması 1960'lı yıllara kadar büyük oranda etkisini gösterirken, merkeziyetçi yapıyı, şirket bazında ölçek ekonomisini ve işletmelerin büyümesini ön plana çıkarmıştır. 1970'li yıllara gelindiğinde petrol şoklarından sonra ortaya çıkan bunalımlar, merkeziyetçi yapının dışına çıkan şirket yönetiminin oluşmasıyla Keynesci politikaların da çözüm olamayacağı fikrine ulaşılmıştır. Üretimde artan zorluklar ve buna yönelik teknolojik gelişmeler 1şı̆̆ında eski sistem yerini yeniliklere 
bırakmıştır. Bilimde genetik buluşlar, teknolojik gelişmeler, enformasyonda devrim, yapılanmada yenilikleri olağan kılmıştır. Yenilik hareketi sonucunda toplumsal, bireysel ve işletme anlamında değişimler söz konusu olmuştur. Herkesin görüşünü önemseyen demokrasi anlayışı, organizasyon yapısı içerinside de birtakım yenilik ve değişikliklere neden olmuştur (Aytaç, 1999, s.27).

\subsection{Gelecekte Girişimcinin Rolï}

Girişimcileri anlayabilmek için içinde yaşanılan topluma, toplumun yaşadığı süreçlere, o süreçleri yaşamasında etkili olan kültüre bakmak gerekir. Nesilden nesle değişen, gelişen ve yeniliklerden etkilenen kuşakların, içerisinde bulundukları zamana kültüre ve tarihe göre şekil aldıkları görülmektedir (Yelkikalan ve diğerleri, 2010, s.500).

Girişimci kavramı zaman içinde değişime uğramış ve anlamı genişletilerek, değişim ve yeniliklerle birlikte daha farklı anlamlar kazanmaya başlamıştır. Her geçen gün farklı türleri oluşmakta ve sadece ortaya yeni bir şeyler çıkarmak yetmemekte, ortaya çıkarılan ürün ya da hizmetin yeni öğelere hizmet edecek şekilde oluşması beklenmektedir.

Girişimciliğin ve girişimci sayısının arttırılması ekonomik ve sosyokültürel anlamda ülkelerin bölgesel, ulusal bazda kalkınmasını sağlayacak çalışmaların başında gelmektedir. Bu yönde atılacak adımlar ve uygulanacak politikalar o ülkede yaşayan toplumun bireyleri arasındaki girişimcilik potansiyelini ortaya çıaracaktır. Eğer girişimcilik vasıflarına sahip, rekabeti göze alabilen, yeniliklere açık, farkındalık sahibi, dışarıya açılabilecek gelişime açık kişilerse bu yönlerini açı̆̆a çıkarıp güçlü yanlarıyla ortaya çıkacaklardır (Perktaş, 2014, s.473).

Girişimcilik her ne kadar desteklense de bazı olumsuzluklarla da karşılaşılmaktadır. Bu anlamda iş kurmak isteyen ve girişimciliğe atılmak isteyenlerin en büyük sıkıntısı finansman bulma sıkıntısıdır. Özkaynakların dışında fon kullanmak isteyen küçük işletmelerin işi zorlaşmakta ve mali açıdan bu fonların altına girmek istemedikleri için bir arayış içerisinde banka kredilerine başvurmaktadırlar. Gelecekte destekler ve kredi oranları arttırılmalı, vergi alımı azaltılarak bürokratik işlemler kolaylaştırılmalıdır. Girişimciliği destekleyen kuruluşlar arasında iletişim kuvvetlendirilerek ortak bir ağ kurulmalıdır. Teknolojik 
girişimcilik tüm dünyada tanıtılmalı ve yaygınlaştırılmalıdır. Bu sayede uluslararası anlamda bir ölçüm yapılarak farklılıkların ortaya çıkmasıyla ekonomiler karşılaştırılır ve açıkların kapanması için çalışmalar yapılabilir (Üzülmez, 2008, s.26).

Devlet eliyle olmayan hür teşebbüs olarak adlandırılan rekabete dayalı özel girişimcilik ne kadar fazla desteklenirse ve artarsa o ülkede o kadar fazla gelişir, refah seviyesi yükselir. Özel girişimciliğin az olduğu ya da kısıtlandığı ülkelerde ekonomik ve sosyal anlamda gelişim yavaş olduğu kadar düşük seviyelerde seyir gösterir. Özellikle gelişmekte olan ülkelerde girişimciliğin biçilen pay oldukça fazladır. Girişimciliğin fazla olduğu toplumlarda kaynakların kullanımı, yeni üretim yöntemlerinin fazlalığı, teknolojik imkanların çokluğu ve bunların topluma kazandırılıp, tanıtıldığ1 görülmektedir. Yapılandırılıp yeni fikirler ve inovasyonlar ışı̆̆ında geliştirilen firmalar, yeni açılan şirketler ülkenin istihdam olanaklarını artırır. Böylece ülke gelişim gösterdiği için ekonomik ve iktisadi kalkınma sağlanmış olur (Üzülmez, 2008, s.21).

Girişimciliğin ülkenin refahını arttırdığı iddiasını destekleyen en önemli nedenlerden biri son dönemlerde girişimciliğin bir iş kapısı olarak görülmesi ve istihdama sağladığı katkı diğeri ise girişimciliğin ekonomiye sağladığı ekonomik katkıların fark edilir düzeyde artmasıdır (Üzülmez, 2008, s.22).

Girişimciliğin artmasıyla birlikte zamanla gelir dağılımındaki eşitsizlikler azalacak kalkınmanın etkisiyle tüm bölgelerde dengeli bir dağılım söz konusu olacaktır. Yeniliklerin teşvik edilmesi neticesinde girişimciler yeni ürünler ve üretim süreçleri geliştirip teknolojiyi de etkili kullanacaklardır. Girişimcilik bireysel tasarrufları teşvik ettiği kadar tekelciliğe karşı bir koruma görevi görecektir (Kuvan, 2007, s.30).

Bilgi çağına geçişin yapıldığı şu dönemde değişim her şeyin merkezinde yer almaktadır. Toplumların anlayışları, bakış açıları, kültürleri, yönetim ve liderlik şekilleri de değişime konu olmaktadır. Bilgi çağında önemli olan fikirler olduğu için ekonomik ve sosyal yapının güçlendirilmesinde etken olan insandır. İnsanın ihtiyaç duyduğu ve geliştirmeye çalıştığı olgu da bilgiyi yönetebilme imkanıdır (Yeniçeri, 2002, s.57).

Girişimci liderlerin yapması gereken, zamana ve teknolojik gelişmelere ayak uydurduktan sonra oluşabilecek olumsuzlukları elimine ederek risk 
almak ama aldığı riski en alt düzeyde tutarak değişimi kendi lehlerine kullanabilmeleridir. Bu duruma örnek olarak Samsung firmasinın ürünlerinin görselliğinde değişime gitmek istemesi ve eski imajını değiştirerek tasarımında yenilik yapmak istemesi ve yönetim kurulu başkanının bu kararı alırken zorlanması gösterilebilir. Firma böylesine zor bir karar aldıktan sonra kitlesel perakendecilerindeki bütün ürünlerini raflardan geri çekerek bu ürünleri daha üst seviyedeki gelir sınıfına sahip kitlelere satmayı hedeflemiş ve o mağazaların raflarında yer vermiştir. Samsung verdiği bu kararla ve aldığ1 risk sonucunda doğru müşteri kitlesine ulaşmış ve karını önemli bir miktarda arttırmıştır (Süzer, 2005).

\section{Girişimcilerle Yapılan Görüşme}

Çalışmada Schumpeter girişimcilik modeli ile 21. yüzyıldaki girişimcilik modelinin benzer ve farklı yönleri incelendikten sonra yaş gruplarına göre girişimci davranışlarındaki gelişim ve değişim incelenerek kuşaklar arasındaki fikir ayrılıkları ve fikir birliklerinin analiz edilmesi ihtiyacıyla 20 katılımcı ile yapılan mülakat sonuçları çalışma grupları ve onlardan alınan bilgiler neticesinde ulaşılan bulgu ve yorumlardan bahsedilecektir.

\section{1. Çalışma Grubu}

Araştırmanın çalışma grubunu oluşturan girişimciler yaşları doğrultusunda 3 gruba ayrılarak kuşak farklılıkları incelenmek üzere birinci grup 28 yaş altı, ikinci grup 28 ve 36 yaş arası ve üçüncü grup 36 yaş üstü olarak belirlenmiştir. Girişimcilik yaptıkları alanlara göre iş grupları da incelemeye dahil edilmiştir. Toplamda 20 katılımcı ile yapılan mülakatlar 8 temel soruya verilen cevaplar doğrultusunda şekillenmiştir. Katılımcılardan dördü 28 yaş alt1, on biri 28-36 yaş arası, beşi 36 yaş üstüdür. 
Tablo 1. Çalışma grubu

\begin{tabular}{ccc}
\hline Katılımcı Adı & Yaşı & İş Alanı \\
\hline A & 22 & Organik Solucan Gübresi \\
& Üretimi ve Satışı \\
B & 23 & Kasap ve Şarküteri \\
C & Fotoğrafçı \\
Ç & 23 & Eğitmen \\
D & 26 & KOSGEB Yatırımcı Destekçisi \\
E & 28 & Aktar \\
F & 29 & Sanayii Sektörü \\
G & 29 & Otomotiv \\
G & 30 & Yazilım \\
H & 30 & Ticaret \\
I & 30 & Avukat \\
I & 31 & Danısmanlık \\
J & 33 & Ticaret \\
K & 35 & E-Ticaret \\
L & 35 & Danışmanlık \\
M & 36 & Sanayii Sektörü \\
N & 41 & Diş Ticaret \\
O & 42 & Emlakçı \\
Ö & 44 & Müteahhit \\
P & 45 & İş Adamı \\
\hline
\end{tabular}

\subsection{Bulgular ve Yorum}

Girişimciler ile yapılan görüşmelerde aşağıda belirtilen 8 soru ve buna ilişkin katılımcıların görüşleri yer almaktadır.

\section{Girişimcilik fikrinin deneyim ve kişilik özellikleri ile olan ilgisi ko- nusunda katılımcı görüşleri:}

Her üç gruptaki katılımcıların görüşleri incelendiğinde büyük bir çoğunluğunun girişimcilik fikrinin deneyimleriyle alakalı olduğu ortaya çıkmıştır. 35 yaşındaki $\mathrm{K}$ adlı katılımcı fikrinin deneyimleriyle ilişkili olduğunu anlatırken "Girişimcilik benim yaşam amacım doğrultusunda yaptığım bir şey. Çünkü dünyaya değer katacak bir şeyler yapmak istiyordum." şeklinde açıklamıştır. 29 yaşındaki $\mathrm{F}$ adlı katılımcı ise diğer katılımcılarının tam tersi yönde bir ifade kullanarak "Girişimcilik fikrim aslında deneyimlerimle alakalı değil, birazcık piyasanın şartlarına uymak zorunda kaldık." ifadesini kullanarak piyasada gördüğü eksikliği doldurma gayesi içinde atılım yaptığını 
belirtmiştir. Katılımcılar arasında, 35 yaşındaki J adlı olan kişi ise "Zamanında yaptı̆̆ım iki girişimcilik deneyiminin biri alakalı idi, diğeri değildi." diyerek iki türlü girişimde de bulunduğunu açıklamıştır. Girişimcilerin kişilik özellikleri konusunda katılımcıların verdikleri yanıtlar arasında çoğunlukla yeni fikirlere açı, araştırmayı seven, sorgulayan ve okuyan, keşfetmeye ve yeniliklere açık, hayal gücü yüksek, meraklı, kararlı, azimli, sabırlı, çözüm odaklı, hırslı, girişken, dürüst, açık sözlü, cesur, ahlaklı, akılcı, mücadeleci gibi özellikler sıralanmıştır.

\section{Katılımcılarn girişimciliğe iten motivasyon kaynaklarn ve eğitim, uz- manlık gibi konular hakkında görüşleri:}

Eğitim konusunda katılımcıların yarısından çoğunun eğitim alarak girişimcilik yapmaya başladıkları görülse de eğitim almayan kesiminde bu konuyla ilgili olarak aileden gelen ve küçük yaşlardan beri sektörün içinde oldukları için deneyimle şekillenen bilgi birikimlerine sahip oldukları sonucuna ulaşılmıştır. Katılımcılardan en çok alınan cevap motivasyon kaynaklarının tutkularından beslendiği yönünde ardından gelen cevap ise aile mesleği olduğu için devam etme fikrine sahip olduklarıdır. İnsanların "Yapamazsın!" demesi üzerine hırslanan katılımcılar olduğu gibi piyasadaki açı̆̆ı görüp girişimcilik yapmaya başlayan katılımcılar da vardır. Bunların arasından 31 yaşındaki I adlı katılımcı orta kuşağı temsil ederken bütün görüşleri toplar nitelikte "Faydal olma arzusu ve başarma azmi girişimciliğge iten nedenlerdir. Motivasyon ise o işin başarıya doğru çıkış yakalamaya başlamasıdır. En başta işe o işe olan inancım motivasyonumdur. Tutkum kesinlikle var. Eğitim konusunda ise evet küçüklükten beri mevcut işimin de içindeydim. Sadece girişimcilik kültürü ile bütünleştirdim" diyerek açıklama yapmıştır. Yine girişimciliğe iten sebeplerden en sık rastlananı ve motivasyon kaynağı olan cümleleri 33 yaşındaki İ adlı katılımc1 "Hep özel sektörde çalıştım ve maalesef hep hakkım olanı saygıyı, ücreti ve anlayışı göremedim. Bu emeğimi kendim için sarf edebileceğimi düşündüm ve kendi işimi 2018 yılında kurdum. Lisans düzeyinde eğitimim yok ancak Ingiltere'de 5 yıllık süreç içerisinde deneyim kazandım. Ayrıca eğitici eğitimi ile birlikte bu alanda uzmanlaştığımı söyleyebilirim. İngilizce öğretmek benim için bir hobi gibi olduğu için tutkum olduğunu düşünüyorum." sözleriyle deneyimlerle elde edilen eğitimin önemini vurgulamıştır. Girişimciliği kendini tanımlamak hatta tabiri 
yerindeyse kendini gerçekleştirme dürtüsü olarak gören ve insanlığa faydayı ön plana koyan bir görüşte olan, üçüncü kuşağı temsil eden 42 yaşındaki N adlı katılımcı "İnsanlığa yararlı yeni birtakım şeyler meydana getirme isteği. Girişimcilik bir ruhtur. Eğitimle geliştirilebilir fakat kazandırılamaz. Uzmanlığı olmayan tutku ile yapılan bir iş. Ben bu konuda eğitimler aldım fakat asıl olan girişimcinin kendisidir. İçinde taşıdı̆̆ı ruhtur." sözleriyle ifade etmiştir.

\section{Girişimcilik kültürünün geçmişten günümü̈ze değişimi ve dijital dö- nüşümün etkileri konusunda katılımcı görüşleri:}

Geçmişten günümüze girişimciliğin değişimi konusunda katılımcılar arasinda tezatlıklar olduğu ortaya çıkmakta ve bunun sebebi olarak kıyaslayacak faktörlerde olan değişim görülmektedir. Geçmişte yalnızca belli bir fikrin olmasının yeterli olduğunu ve o zamanlarda daha kolay olduğunu savunan D, F, J adlı katılımcılar bir ve ikinci kuşakta yer alırken geçmişte daha zor olduğunu savunan $\breve{G}$ ve $\mathrm{O}$ adlı katılımcllar ikinci ve üçüncü kuşakta yer almaktadır. Bunların arasında kolaylık veya zorluk olarak fark olmadığını belirten 30 yaşındaki G adlı katılımcı ise orta kuşakta yer almaktadır. D adlı katılımcının konuyla ilgili görüşleri "Girişimcilik geçmişte daha basitti. Girişimcilik hayatına girmek için sadece bir fikre sahip olmak yeterliydi. Ancak artık günümüzde bir ürünü/hizmeti satabilmek eskisi gibi kolay değil. Bu sebeple günümüz girişimcisi ürettiği ürüne sunduğu hizmete herhangi bir aşamada diğerlerinde bir farklılık katmadı̆̆ sürede piyasa yer edinememektedir. Bu sebeple günümüz girişimcisinin değerlendirmesi gereken birçok farklı parametre vardır." şeklindedir. Yine bu görüşü destekleyen F adlı katılımcı "Geçmişte daha çok insanlar sözlerine binaen hareket ediyorlardı. Bu da bir işe başlamak adına sanki daha kolaydr. Şu an imkânların ne kadar çok olduğu düşünülse de o dönemde imkânlar az olduğu takdirde bile insanlar bir girişim fikrine daha rahat başlayabiliyordu çünkü rakibin azdl, girebileceğin sektör sayısı çok fazlaydı, bir işi bilme-sen bile yapabiliyordun ya da yapmak zorunda kalıyordun." sözleriyle ifade etmiştir. Tam tersi yönde fikir beyan eden $\mathrm{O}$ adlı katılıma ise "Girişimcilik yıllar içinde eviriliyor. Geçmişte sermayeye ve bilgiye ulaşım zordu. Şimdi ise dünya ile entegre bir çă̆dayız. Bilgiye ulaşmak kolay. Bu da girişimleri hayata geçirmekte işleri kolaylaştırıyor. Günümüzde şirketler değgişime açık olmadıkları ve müşteri ihtiyaçların görmekte geç kaldıkları için dijital dönemin gereklerini yerine getiren diğer genç şirketlere karşı rekabet ermek de 
geride kalıyorlar. Bu durum da ömürleri kısalıyor." sözleriyle görüşünü dile getirmiştir. İki tarafın görüşleri dışında kalan ve herhangi bir fark olmadığını savunan G adlı katılımcı "Girişimcilik, para vb değerlerin olmasıyla her zaman etkili olan bir kavramdir. Eski ile yeni arasında girişimcinin yapabildikleri arasında bir fark yoktur. Çünkü girişimciler her zaman firsatları değerlendiren insanlardır ve bu firsatları her an, her durumda hayata geçirmek girişimciliğin bir parçasıdır ve bugüne kadar da bugün de hatta bugünden sonra da firsatları değerlendiren bir girişimci her zaman olacaktır. Yalnız eskiye göre günümüzde girişimcilerin, iş dünyasında daha fazla ilgi ve değer gördü̆̈̈̈ de atlanılmayacak bir detaydır." diyerek ifade etmiştir. Bunlar dışında $C$ adlı katılımcı geçmişten günümüze girişimciliğin ivme kazandığını ancak gelecekte düşüşe geçeceği ile ilgili bir tahminde bulunmuştur. Dijital dönüşüm ekseninde ortak bir görüş birliğiyle olmazsa olmaz düşüncesiyle zamana ayak uydurmak adına fikirlerin internet ve teknoloji çağıyla orantılı ilerlemesi gerektiği katılımcılarca onaylanmıştır. Genel bir özet mahiyetinde 36 yaşındaki L adlı katılımcı karşılaştırma yaparak görüşlerini şu şekilde ifade etmiştir: "Türkiye'de girişimcilik son 15-20 yıllık bir mazisi olan, özellikle son 10 yılda gelişen bir kavram. Dünyaya bakarsak eğer özellikle gelişmiş ülkelerde bu kavramin gerek kültürel gerekse yasal zemininin daha sağlam ve köklü olduğu görülebilir. Şahsi görüşüm girişimcilik kavramın geç yakaladığımız ama çok büyük bir kayıp yaşamadığımız yönünde. Kurulan işlerin içeriğine (NACE Kodu) bakllırsa bile dijital dönüşümün etkisi görülecektir. 5-6 yıl önce yazdığımız girişimcilik projelerinde teknik cihazlar (bilgisayar, barkod okuyucu, barkod yazıcı vb.) sayısı sinırl iken şu anda perakende yapılan her projede bu ürünler girişimciler tarafindan olmazsa olmaz görülüyor. Yeni nesil daha materyalist ve işlemsel hız tutkunu bir noktada, teknoloji, maddeci yaklaşım ve hız kavramları uzun vadede tatminsizliklere yol açabilecek. Bu sürecin dünya çapında bir politika ile izlenmesi gerekiyor."

\section{Girişimin başarıya ulaşmasında geçilmesi gereken süreçler ve gelişen, değer kaybetmeyen piyasalarda olması konusunda katılımo görüş- leri:}

Katılımcıların tamamına yakını girişimcilik fikrinin bulunduğu iş alanının gelişen bir piyasada olduğunu ancak değer kaybetme konusunda değişimlerin söz konusu olabileceği yönünde açıklamalarda bulunmuştur. 
Genel itibariyle gelişen ve değer kaybetmeyen bir piyasada yer aldıkları düşüncesi hâkim olmakla birlikte bu konuda hemfikirdirler. B adlı katılımcı süreçlerin başarıya ulaşmasında kaynak olarak paranın varlığının önemli olduğunu fakat devlet desteğine de çok fazla güvenilmemesi gerektiğine değinmiştir. $\mathrm{H}$ adlı katılımcı girişimlerin başarıya ulaşmasında yasal prosedürlerin düzenlenmesi gerektiğine, gereksiz teferruatların azaltılmasına, piyasalara hâkim olma düzeyine ve yetkin kişilerle çalışılması konusuna vurgu yapmıştır. L adlı katılımcı her şeyin başlangıç noktasını oluşturan temelde doğru etüt yapılması ve devamının bu şekilde geleceği görüşündedir. $\mathrm{D}$ adlı katılımcı girişimciliğin başarıya ulaşmasında gereken süreçler hakkında "Yeterli sermaye elde edilmeli, zayıf ve güçlü yanlar tespit edilip, ikame planlar üretilmeli, rakipler iyi analiz edilmeli, müşteri kitlesi iyi bilinmeli ve isteklerine cevap verebilmek için yeniliğe açık olunmahdır." sözleriyle ifade etmiştir. Ç adlı katılımcı da girişimciliğin temel ölçütlerini ele alan bir açılamayla "Bir girişimin başarıya ulaşması için tasarlama, pazar araştırması, olumlu-olumsuz durumların göz önünde bulundurulması, hazırlıların tamamlanması, uygun koşullar sağlandığında hayata geçirilmesi ve devamında da sıkı kontroller yapılması gerekmektedir." diyerek sürecin yönetilmesi gerektiğini söylemiş̧tir. $\mathrm{C}$ adlı katılımcı ise araştırmaların gerekliğine değinmekten ziyade girişimciliğin istek ve ahlaki boyutuyla ilgili bir gelişimden söz etmiştir. "Hayal insanı hep ileriye taşır fakat bir girişimci ne kadar hayalperestse o kadar da şartlar konusunda objektif olup eksikleri artıları kendi terazisinden geçirip her zaman için önlem almalıdır. Önlem alı ve hayal kurup, yeteri kadar çalışmalı ve en önemlisi iş ahlakına sahip olmalı. Bunların başarıyı doğuran etmenler olduğunu düşünüyorum." Son kuşağ temsil eden 49 yaşındaki P adlı katılımcı ise başarının ölçütü olarak "Bizim dönemimiz için şunu söyleyebiliriz: Tırnaklarıyla kazıma hikâyesi vardır ya, tırnaklarıyla kazıdığı zaman bir işveren ancak o zaman başarıya ulaşır düşüncesi bizde hala mevcuttur ve bu dönem için hâkim olan anlayıştır. Bizler de aynı mantıktayız dolayısıyla girişimci-yatırımcı olmak sizi ancak çok çalışmayla bir yerlere götürebilir." sözleriyle çalışmayı ve emeği kıstas olarak ele almıştır. 


\section{Girişimcilik fikrinin problemlere çözüm üretmesi ve olası problemler konusunda hesaba katılmayan kör noktalar konusunda katılımo gö- rüşleri:}

Girişimcilik fikrinin problemlere çözüm üretmesi ve olası problemlerin hesaba katılmayan kör noktaları konusunda katılımcıların hemen hemen hepsi girişimcilik fikrini problemlere karşı yapılmış çözümler olarak tanımlıyor. A ve E adlı katılımclar ortak paydada buluşarak bu soruyu en önemli olan unsurun insan sağlığına kattığı fayda olarak cevaplamışlardır. Diğer katılımcılardan I adlı katılımc1 "Bence girişimcilik bir probleme çözüm üretmiyorsa boşa yapılıyordur" sözleriyle girişimcilik fikrinin toplumda bir eksikliğe cevap vermesi gerektiğini savunmuştur. $M$ adlı katılımcı konuya ahlaki değerlere de değinerek şu şekilde cevaplamıştır: "Pazar araştırması, pazara sunulacak ürün ya da hizmetin fizibilite çalı̧̧masın yapmak, ürün ya da hizmetin ulaşabileceği kitleyi belirlemek, kâr marjların belirlemek, kaliteli ürün ve hizmet sunmak, sonuca varmak. Ahlaki düzeyin üst seviyede olması lazım. Kâr marjlarının çok yüksek değil de her iki tarafı da memnun edecek seviyede olması lazım. Sonuç olarak son tüketiciye gidene kadar alım gücünün düşmemesi lazım. Gerekli yatırımların yapılmadığı fikrindeyim" Üçüncü grupta yer alan 44 yaşındaki $\mathrm{O}$ adlı katılımcı günümüzde ki problemlerden örnekler vererek girişimciliğin gözükmeyen noktalarından bahsetmiştir: "Her girişimcilik fikri ve bundan doğan ürün/hizmet çoğu zaman probleme çözüm üretir ve insan ihtiyaçların karşılar. Günümüzde problemler şunlardır: Doğru yapılmayan fizibiliteler, sermaye yetersizliği, haksı rekabete maruz kalmak, mentor ve danışman desteği bulamamak. Kör noktalar genelde pazarı ve ülke ekonomisini doğru analiz etmemek sonucunda maliyet, satış fiyatı ve fire payı gibi gözükmeyen faktörleri dikkate almamaktan kaynaklanabilir." Bu soru karşısında 49 yaşında olan ve yaş itibariyle daha tecrübeli olan P adlı katılımcı girişimcilik coşkusunun önemli olduğu ve elinizde olmayan nedenlerden dolayı karşılaştığınız problemlere şöyle cevap veriyor; "Girişimcilik coşkusu denen bir tabir var, girişimciliğin ruhu değil de coşkusu bizim açımızdan çok daha önemli, dolayısıyla "Hadi hareket et." duygusunu getirdiğin zaman ve bunu kendine kabul ettirdiğin zaman elbette bu hareketin bereketiyle karşılaşıyorsunuz ama her daim, zaman zaman devlet sizin önünüze kontrol edemeyeceğiniz faktörlerle çıktı̆̆ında orada istediğiniz kadar girişimcilik ruhunuz olsun o zaman sizi aşamayacağınız engellerle yüz yüze bıraktığında batışınıza 
kadar bu sizi götürüyor. Bunun da aslında size getirdiği öğreti şu olmalı: Sektör değiştireceksiniz, esnek olacaksınız ve dijitalleşeceksiniz." İkinci grupta yer alan 36 yaşındaki L adlı katılımcı girişimcilik problemlerine dünya ekonomisine de bağlayarak aslında kendi sektörü ile birlikte bu problemlere danışmanlık yaptığını belirtmiş olup şu şekilde cevaplamıştır; Birçok probleme çz̈̈üm üretiyoruz, danışmanlık hizmetinin ana konusu aslında bunu teşkil ediyor. İşletmelerin oluşan problemlerinin giderilmesi veya en az seviyeye indirilmesine yardımcı olmaya çalışıyoruz. Tüm dünya ülkelerinde de geçerli olmakla birlikte, Türkiye gibi ekonomisi kurllgan olan, siyasi ve gündelik olaylardan etkilenen ülkelerde girişimciler için en önemli konu finansal altyapının sağllklı bir zemine oturtulmasıdır. Danışmanlık hizmeti vermiş olduğumuz girişimcilerin bu konuda yeterli olmadıklarmı, doğru bir araştırma ve finansal etüt yapmadan işlerine yöneldiklerini görüyoruz. Özellikle KOSGEB gibi hibe veren kuruluşların sağladığı mali destek bu alanda bir körlük oluşturuyor. Girişimci kamudan alacağı hibe desteği ile işlerini yürütebileceğini, finansal olarak yeterli olacağını düşünüyor. Bir diğer konu ise maliyetlerin belirlenmesinde doğrudan/dolaylı maliyet kalemlerinin net olarak çıarılamaması olmakta. Yapılan bu hata sonrasında ürünün veya hizmetin fiyatına doğrudan yansıyor. Maliyet ve satış fiyatı arasındaki kar oranına yansıyan bu hata uzun vadede ciddi kar/zarar sapmalarna neden olabiliyor."

\section{Girişimci yatırımcı ilişkisinin düzeyi ve yatırmların yeterliliği ko- nusunda katılımcı görüşleri:}

Yatırımların yeterliliği konusunda katılımcıların ikiye ayrılmış olduğu görülmektedir. Bazı katılımcılar kati bir şekilde yatırımcıların, girişimciler gibi düşünmediğinden dolayı yetersiz olduğunu savunurken bazı katılımcılar yatırımların özellikle devlet tarafından oldukça yeterli olduğunu savunmuşlardır. Örneğin ilk grupta yer alan ve tecrübesi daha kısıtlı olan 23 yaşındaki B adlı katılımcı "Başka ülkelerde nasıldır bilmiyorum ancak ben işyerimi açarken en yakınlarımdan manevi destek bile görmedim, bırakın maddi destek olunacağı. Yani girişimciye yatırımcı olarak destek verecek insanlar olduğunu pek düşünmüyorum." sözleriyle düşüncelerini paylaşırken tam tersini savunan ve ikinci grupta yer alan I adlı katılımc1 "Gerekli yatırımlar var. Ama herkes fikrini çok iyi sandı ̆̆ için kötü fikirler yada fon alamayacak fikirlerde fon alamayınca problemler oluşuyor. Bence herkes işini iyi analize etmelidir. 
Girişimci yatırımcı ilişkisi mesafesini dengede tutan bir ilişki düzleminde olmalıdır." diyerek yeterli yatırımların olduğunu savunmuştur. K adlı katılımcı ise yatırımcı ilişkisini iki yönlü olarak ele alıyor ve şu şekilde tanımlıyor; "Yatırımo bulmak hem kolay hem zor. Yaptığın işe bağll, herkesin yaptığı, işin içinde ticaret olan bir şey yapıyorsan, al sat yapıyorsan o kadar artı $\mathrm{ki}$ bu melek yatırımcilar, platformlar, vc'ler, founding'ler. Güzel anlatabiliyorsan buluyorsun. Ben bulamadım ama öyle çokta daha böyle aramadım yani. Şimdilik kendi başıma idare ediyorum. Bence artık eskiye göre çok daha kolay" Bu konuya L adlı katılımcı girişimci ve yatırımcı alanında sağlıklı bilgi akışının olmadığını ve bu konuda yasal mevzuat ve destek mekanizmasının da bulunmadığını savunmuştur. Üçüncü grupta yer alan P adlı katılımcı ise tecrübelerinden yola çıkarak eskiye nazaran şuan devletin ve yatırımcıların girişimcilere desteklerinin oldukça arttığını şu cümlelerle belirtmiştir; " $Y a$ tırımo ve girişimci tarafina baktığımız zaman bugün devletin açmış olduğu o kadar çok imkanlar var ki. Yeni jenerasyonun devlet tarafindan çok daha fazla desteklendiğini görebiliyorsunuz. Bizim jenerasyona göre devletin desteği olmadan, devletin finansman olmadan çok fazla bir girişimciliği, bir atılımı yerine getirmek mümkün değil çünkü alt yapıyı kullanıyorsunuz her şeyden önce. Tabii bu bizim alanımız için geçerli ama her hâlükârda devletin sizi destekliyor ve sermaye gücünde önünüzü açıyor olması çok önemli. Girişimcinin melek yatırımcı ile buluşması bugünkü koşullarda çok daha kolay ve hızlı çünkü teknolojiyi çok iyi kullanıyorlar bu yüzden de sermayenin açık olduğunu görüyorsunuz. Aklın kullanan herkes sermaye bulmakta hem özgür hem de hizlı yatırımlar yapmakta ancak bizim dönemimiz için aynı şeyi söylemek çok kolay değil."

\section{Global arenadaki girişimcilik kültürü ile ülkemizdeki durumun kı- yaslanması konusunda katılımo görüşleri:}

Katılımcılardan bazıları bu soru karşısında yeterli bilgiye sahip olmadıklarını belirtseler de birtakım görüşlerini paylaşmışlardır. Verdikleri cevapların çoğunda aynı fikirde oldukları görülmekte ve girişimcilik kültürü anlamında global arenada çok geride olduğumuz kanısındadırlar. A ve B adlı katılımcıların verdikleri cevaplar global çapta girişimciliğin, ülkemize nazaran daha ileri seviyede olduğu yönündedir. I adlı katılımcı ise bu soruya pozitif bakış açısıyla yaklaşarak "Girişimcilik kültürünü yeni öğreniyoruz. Ama biz başaracağız. Çok güzel fikirlerimiz var. Hayata geçirip örnek 
olacağı" sözleriyle ifade etmiştir. P adlı katılımcı ise "Gelişmiş ülkelerle gelişmekte olan ülkeler diye ayırmak belki literatüre daha uygun olabilir ama gelişmiş ülkelerin girişimcilik yapısı çok daha farkl, en azından günümüzde çok daha farkl. Bir kere sermayenin ve fikrin hızlı buluşumu orada daha mümkün ancak özellikle gelişmekte olan ülkelerde hâlâ tırnaklarıyla kazıma meselesi veya çok çalışma hikâyesi geçerli yani bir yanda sermaye yoğun, bilgi yoğun bir girişimcilik sanayi ve dünyadan bahsederken bir yanda emek yoğun bir girişimcilikten bahsediyoruz. Emek yoğun olunca bir anda sizi geriye itebiliyor çünkü verimliliği de ön plana aldığınız zaman siz hangi alan-da güçlü olduğunuzu çok iyi kurguluyor olabilmeniz lazım. Bu sadece bireysel anlamda değil ülkeler içinde geçerlidir. Verimli olduğunuz şeyi yapacaksınız. Çin bugün emek yoğun meselesinde çok daha avantajlı bir durumdaysa emek yoğun işleri yapıyor gerçi Çin'i ayrı değerlendirmek lazım. Çin emek yoğun avantajın kullanabildiği gibi sermaye yoğun avantajını da iyi kullanabiliyor ama özellikle Hindistan gibi gelir dağılımının çok daha bozuk olduğu ülkeleri ele aldığımızda, emek yoğunda çabanın daha fazla olması gerektiğini söylemek mümkün." sözleriyle düşüncelerini paylaşmıştır. Ö adlı katılımcı ise global dünyada sadece girişimcilik ekseninde değil her alanda ülkemizin geride olduğunu savunmuştur.

\section{Katılımcıların bugünkü koşullarda girişimciliğe adım attığı yaşta ol- ması durumunda değişim yapılması gerekenler konusunda görüşleri:}

Katılımcıların bu soruya verdikleri yanıt yaş gruplarına göre değişkenlik göstermektedir. Bazı katılımcılar girişimciliğe yeni başladıkları için tecrübeleri konusunda değil de gözlemleri konusunda cevap vermişlerdir. Örneğin ilk grupta yer alan 23 yaşındaki $C$ adlı katılımcı 7 ay kadar önce adım attığı girişiminde, öncelikle resmi prosedür hakkında daha çok bilgi sahibi olmak istediğini belirtmiştir. Yine aynı grupta yer alan D adlı katılımcı üniversite bitirmenin her şey olmadığını kendisini geliştirmenin daha farklı yolları olduğunun farkındalığına varmıştır. İkinci grupta yer alan 30 yaşındaki $\mathrm{G}$ adlı katılımcı ise teknoloji alanında girişimlerinin olmasını ve insan hayatını kolaylaştıracak ürünler geliştirmek istediğini belirtmiştir. I adlı katılımc1 "Daha çok tecrübe ve finans gücüm olmadan kalkışmazdım. Çünkü çok büyük problemler yaratıyor. Birde ben kendi yaşım değil de işlerin daha hızlı olduğu satışların bol olduğu bir dönemde olmak isterdim. Şu an kendi sektörümde bazı handikaplar var. Bu da bizi hayli zorluyor." sözleriyle 
düşüncelerini belirtmiştir. J adlı katılımcı da daha çok fizibilite yapması gerektiğini savunmuştur. Ö adlı katılımcı ise I adlı katılımcıya benzer cevap vererek sermaye konusunda daha çok yatırım yaparak teknoloji ve dijital pazar gücünü kullanması gerektiğini belirmiştir. Üçüncü grupta yer alan P adlı katılımcı yine tecrübeleri mahiyetiyle şu şekilde cevap vermiştir; "Çok şeyi değiş̧irirdim. Bir kere insan yaşının, zamanının kıymetini çok iyi bilmesi lazım. Şu anda yirmili, otuzlu yaşlarda olan insanlarda inanılmaz bir dinamizm olması lazım. Ĕger ben şu anda işe başlayacak durumda olsam ve aynı işi yapıyor olsam kesinlikle dünyaya açılırdım. Şu anda ulusal bir çalışma ağımız var, şu anda sadece yerel bölgede bizim şubelerimiz var ama bunu kesinlikle uluslararası bir arenaya taşırdım. Bugünün uluslararası arenası derken küreselleşmeden bahsediyorum aslında. Küreselleşmenin getirdiği şartlarla bunu söylüyoruz fakat literatüre baktığımız zaman bundan biraz daha tersine doğru bir gidişatın da olduğunu görmek mümkün. Son zamanlarda küreselleşmenin negatif etkisi ve özellikle ulusalcllık, yerelcilik daha ön plana doğru çıkmaya başlayan bir akım şekline dönüştü dolayısıyla bu tekrar bizim nesillere doğru geri getirir mi bazı şeyleri bilinmez ama her hâlükârda bilgi toplumunun gereği olarak insanlar çok daha seri kararlar alabilirlerdi. Ben eğer o yaşımda olsaydım öyle tahmin ediyorum, ulusal düzeyde bile olsa daha seri ve hızh bir takım ürünlerin oluşmasın veya çok daha esnek davranmayı başarabilirdim."

\section{Sonuç ve Değerlendirme}

Katılımcilar 21. Yüzyılda olan durumu temsil ederken Schumpeter ise girişimciyi toplumda değişimi yaratacak kişi ya da kurum olarak tanımlamakta, girişimciliğin temelini yenilik, yaratıcılık ve değişim yaratma olarak görmektedir. Sosyal lider olan, inovasyon ve yenilik yapan, sürekli ilerleme sağlayan, uyanık ve cesaret sahibi kişi olarak girişimciyi tarif etmektedir (Odabaşı, 2005, s. 91, Dolgun, 2006, s. 175). Katılımcıların yaklaşımında ise daha ziyade içinde bulunulan şartların getirdiği bir zorlama söz konusudur. "Şartlar" hele de mevcut iş yapıları kendilerini var olmaya sürükleyiş gibi bir anlayış söz konusudur.

Katılımcların yanı sıra Schumpeter, girişimcinin motivasyonu ne olursa olsun ister çevresel ister teknolojik her türlü yatırım fırsatını fırsata çeviren kişi olarak görmektedir (Dolgun, 2006, s. 174). Yine girişimciliğe iten nedenler arasında, bireyler güdüleri, dürtüleri, gelenek ve 
görenekleri ölçüsünde ekonomik faaliyetlerin büyük bir oranı hatta daha büyük çoğunluğunu bu temel üzerinde görmüştür (Schumpeter and Takata, 1998, s. 8). Dolayısı ile motivasyon ve hirs yapma meselesinde çalışmaya katılan katılımcıların beyanları da aynı yönde seyretmektedir.

Üç nolu grup sorulara verilen cevaplar analiz edildiğinde, geçmişten günümüze girişimciliğin ve girişimcilik coşkusunun basitten karmaşığa doğru gidildiğini söylemek mümkündür. Gittikçe daha da karmaşık bir hal alacağ 1 ifade edilmektedir. Schumpeterde ifade edilen düzeyde basit bir yaklaşımın olmadığı anlatılmaktadır. Katılımcıların yanı sıra Schumpeter, girişimcinin motivasyonu ne olursa olsun ister çevresel ister teknolojik her türlü yatırım fırsatını fırsata çeviren kişi olarak görmektedir.

Schumpeter'e göre girişimci olmanın kıstası sahip olunan bir işletmenin ya da sermayenin varlığı değil de önceden ortaya çıkarılmamış, gerçekleştirilmemiş bir yeniliğin veya fikrin oluşmasından, orta atılmasından geçer. Elde bulunan kaynakları önceki işlerden daha verimli ve yeni işlere yönelten girişimcilik modern ekonominin özüdür (Er, 2013, s. 83). Altı nolu grup sorulardan elde edilen bilgi, her ne kadar yenilikçi fikirleriniz olsa da devlet desteği ve içinde bulunulan durum girişimcilik için engeller ortaya koymaktadır. Asıl girişimcilik çıkan engelleri aşmada gösterilen mücadele ile ölçülebileceği ifade edilmektedir.

Girişimin başarıya ulaşması için Schumpeter yeniliği ön plana alarak yaratıcı yıkıma neden olan ve dengesizlikler üzerinde denge faktörü olan ekonomik değişimi sağlayan yeniliklerin ve yeni bileşimlerin ortaya çıması olarak görmektedir. Girişimci bu süreçte değişime ve yeniliğe ulaşmak için irade gücü ve sosyal çevre tarafından eleştirilere veya komik duruma düşme gibi şeylere karşı dirençli olmalıdır. "Riski iyi yöneterek, net olmayan durumlarla baş edebildiği müddetçe başarılı olur" şeklinde bir anlayış mevcuttur. (Whelan and O'Gorman, 2007, s. 82). Shumpeteryan sonrası nesillerde girişimcilikte başarının devamına ilişkin soruya daha ziyade yenilikçi fikirlerle değil, karşılaşılan rekabetçi ortam için dönüşüm stratejilerini iyi uygulayan kişiliklerin başarısından söz edilmekte, ahlaki normlara da önem verilmesi gerektiği ifade edilmelidir şeklinde cevap alınmıştır.

Schumpeter'e göre, girişimcilerin ekonomik gelişmeyi sağlamak için liberal kapitalist sistem içinde dinamik bir aktör olarak yer almaları, araştırmalar, buluşlar, icatlar yaparak üretime yenilik getirmeleri 
gerekmektedir. Schumpeter' in iktisat teorisine göre bu şekilde davranmayan girişimcilerde ve onların yaşadığı toplumlarda rekabet yoğunlaşacak, kar oranı azalacak ve faiz hadleri çok düşük seviyelere inecektir (Dolgun, 2006, s. 174). Dinamik girişimci olarak yaratıcı yıkım yaşayan, yenilik arayışı içinde olan, eski yöntemleri bırakarak yeni yöntemleri işleve sokan, problemlere çözüm üreterek ekonomik büyümenin sağlanması önemli bir yapı taşı olacaktır (Müftüoğlu ve Durukan, , 2004, s. 42). Schumpeter problemlere çözüm anlamında kapitalist endüstriyel toplumun gelişme sorununa ışık tutmak amacıyla irdeler ve kendi kendini yenileyen statik bir akım tablosu yerine dinamik bir gelişim modelini tercih eder.

Katılımcıların fikirleri göz önüne alınarak Schumpeter'in görüşlerinin de örnek alınması gerektiği ve değişimin ne derece önemli olduğu vurgulanmaktadır. Çünkü eski girişimcilik yargılarından; yani sadece riski göze alan, cesaret sahibi olan girişimcilerin yerine sürekli gelişim ve değişim içerisinde olarak yenilikle desteklenen, kendisini yenilikle yenilenen bir anlayış hâkim olmakta küreselleşen dünyada rakiplerinden ayırt edilmeyi sağlayan ve önemli güç olarak yenilikçi girişimcilik kavramı gelmektedir (Er, 2013, s. 76). 


\title{
EXTENDED ABSTRACT
}

\section{Schumpeteryan Entrepreneurship And 21st Century Entrepreneurship Approaches: A Qualitative Research on Y Generation Entrepreneurs}

\author{
Sabri Öz - Nazlıcan Dindarik - Ferdi Duman \\ Istanbul Commerce University
}

The concept of entrepreneurship has gone through many processes that have evolved from past to present. It is used in different sciences, especially in business and economics, and is affected more by changes and developments especially in the 21st century.

The number of recent academic studies on entrepreneurship is also increasing. In this sense, Schumpeter brought a new perspective to the concept of entrepreneurship, emphasizing the concept of innovation as a dynamic element of entrepreneurs rather than providing more advanced innovation-innovation is the most important part of the process of creative destruction that provides continuous progress. On the other hand, creative destruction refers to the disappearance or serious contraction of the pre-existing but not able to keep up with the change in the technological age, with the development of markets adapted to innovation with their returns in the information age.

In the 21st century, innovation, creativity and change come to the forefront in the success of entrepreneurs due to the competitive environment. In this study, individual characteristics of entrepreneurs in the 21st century and individual characteristics of Schumpeter entrepreneurs were emphasized and their differences or similar aspects were revealed. The development process of entrepreneurship is mentioned and information is given about the role of entrepreneur in the future.

After the literature section in the first two chapters, in the third part, entrepreneurs selected from the $\mathrm{X}, \mathrm{Y}$ and $\mathrm{Z}$ generations were divided into 3 groups in line with their ages. The first group was identified as under 28 years old, the second group was between 28 and 36 years and the third group was over 36 years. Business groups were also included in the study 
according to their fields of entrepreneurship. Interviews with a total of 20 participants were based on the answers given to 8 basic questions. According to the results obtained from the evaluation, while Schumpeterian entrepreneurship theories are basically preserved, it is seen that in some areas the world is differentiated due to transformation.

According to Schumpeter, entrepreneurs need to be a dynamic actor in the liberal capitalist system and bring innovation to production by making researches, inventions and inventions. According to Schumpeter's economic theory, in entrepreneurs and societies where there are no efforts to innovate production, competition will intensify, the rate of profit will be reduced and interest rates will fall to very low levels. As a dynamic entrepreneur, it will be an important building block for creative destruction, seeking innovation, abandoning old methods and activating new methods, and providing economic growth by producing solutions to problems. Schumpeter examines in order to shed light on the development problem of capitalist industrial society in terms of solutions to problems and prefers a dynamic development model instead of a self-renewing static flow.

Taking into consideration the opinions of the participants, it is emphasized that Schumpeter's views should be taken as an example and how important the change is. Because the old entrepreneurship judgments; In other words, the concept of innovative entrepreneurship as an important power, which distinguishes itself from its competitors in a globalized world, is dominated by innovation, which is supported by innovation in continuous development and change, instead of entrepreneurs who only take risk and who have courage.

The target audience selected for the interviews in this study is very important. Although the $Y$ generation is predominant, the ages of the selected businessmen and entrepreneurs are given as tables. In this way, it is stated that Schumpeterian entrepreneurship should or should not be seen theoretically. One of the important points for this study was to see the characteristics of today's entrepreneurship. Many results which can be expressed as ancillary results have been included in the study. These causal and consequence relations, which are not actually included in the main objectives of the study, are particularly important in terms of revealing the entrepreneurial characteristics of the twenty-first century. 
Participants represent the situation in the 21st century, while Schumpeter defines the entrepreneur as the person or institution that will create change in society, and sees the basis of entrepreneurship as innovation, creativity and change. It describes the entrepreneur as a social leader, an innovator and innovator, who makes continuous progress, is alert and courageous. On the other hand, in the approach of the participants, there is a compulsion due to the conditions. There is an understanding of Current condition, in particular as existing business structures are dragging themselves into existence.

\section{Kaynakça / References}

Akpınar, S. (2009). Girişimciliğin temel bilgileri. Kocaeli: Umuttepe Yayınları 1.bask1.

Akyos, M. (2004). Firma düzeyinde yenilikçilik (yenilik) ve bilgi yönetimi. http://www.sistems.org/know_info_ozet.htm adresinden 04.03.2019 tarihinde erişilmiştir.

Alkan, M. (2014). Girişimcilerin girişimcilik, inovasyon yapma, inovatif düşünce ve inovatif girişimcilik düzeylerinin incelenmesi. Yüksek Lisans Tezi. Hasan Kalyoncu Üniversitesi Sosyal Bilimler Enstitüsü, Gaziantep.

Antonelli, C. (2009). From the classical legacies to the economics of complexity. Economics of Innovation and New Technology, 18(7), 611-646.

Arıkan, S. (2002). Girişimcilik. Ankara: Siyasal Kitabevi.

Aşkın, A., Nehir, S., ve Vural, S. Ö. (2011). Tarihsel süreçte girişimcilik kavramı ve gelişimi. Girişimcilik ve Kalkınma Dergisi, 6(2), 57-58.

Aydoğmuş, O., Türkcan, B., Tunali, E., ve Kopurlu, B. S. (2009). Kriz teorileri: Kondratieff, Schumpeter ve Wallerstein. Ege University, Working Papers in Economics, 13, 13-14.

Aytaç, R. (1999). Elazığ'da girişimcilik ve girişimci kültür Elazığ sanayi ve ticaret odasına kayıtlı işadamları üzerine sosyolojik bir inceleme. Yüksek Lisans Tezi, Frrat Üniversitesi Sosyal Bilimler Enstitüsü, Elazığ.

Basılgan, M. (2011). Ekonomik gelişmenin yaratıcı yıkımı: Schumpeteryan girişimci. Amme İdaresi Dergisi, 44(3), 27-56.

Başar, M., ve Tosunoğlu, B. T. (2006). Değer Yaratımında iç girişimciliğin değişen boyutu: Bilgi girişimcilerin rolü. Girişimcilik ve Kalkınma Dergisi, 1(1), 124-125. 
Bozgeyik, A. (2005). Kriz dönemlerinde girişimcilik neden daha önemli?

http://www.bilgiyonetimi.org/cm/pages/mkl_gos.php?nt=577 adresiden 05.03.2019 tarihinde erişilmiştir.

Bozkurt, Ö. Ç., Kalkan, A., Koyuncu, O., ve Alparslan, A. M. (2012). Türkiye'de girişimciliğin gelişimi, girişimcilik üzerine nitel bir araştırma. Süleyman Demirel Üniversitesi, Sosyal Bilimler Enstitüsü Dergisi, 5(7), 233-234.

Chen, T., ve Chen, S. H. (2001). Global production networks and local capabilities. East-West Center Working Papers, Economic Series, 15, 2-3.

Coulter, M., ve Robbins, P. S. (2003). Management (7.bs). New Jersey: Prentice Hall.

Çelik, A. (2006). Bir istihdam politikası olarak girişimcilik. Uluslararası Girişimcilik Kongresi. Dizi: 11 No: 86, s. 468-469. Kırgızistan Bişkek: Türkiye Manas Üniversitesi İ.İ.B.F.

Dolgun, U. (2006). Schumpeter'e göre ekonomik gelişmede girişimcinin dinamik rolü. İstanbul: İstanbul Üniversitesi.

Drucker, P. F. (1998). The discipline of innovation . Harward Business Review, 56.

Durukan, T. (2006). Dünden bugüne girişimcilik ve 21. yüzyllda girişimciliğin önemi. Girişimcilik ve Kalkınma Dergisi, 1(2), 29-30.

Er, P. H. (2013). Girişimcilik ve Yenilik Kavramlarının İktisadi Düşüncedeki Yeri: Joseph A. Schumpeter. Selçuk Üniversitesi Sosyal Bilimler Enstitüsü Dergisi, 5(4), 76-85.

Gül, H. (2005). Bilgi Toplumu Liderliği Karizmatik Liderliğin Sonu Olur mu? http://www.bilgiyonetimi.org/cm/pages/mkl/_gos.php?nt=223 adresinden 05.04.2019 tarihinde erişilmiştir.

Hebert, R. F., ve Link, A. N. (1989). In search of the meaning of entrepreneurship. Small Business Economics 1, 39-49.

Hisrich, R. D., ve Peters, M. P. (1998). Entrepreneurship. United States: The McGraw-Hill Book Co. Fourth Edition.

İraz, R. (2005). Yaratıcılık ve yenilik bağlamında girişimcilik ve KOBİ'ler. Konya: Çizgi Kitabevi.

Kalantaridis, C. (2004). Veblen and the entrepreneur. International Rewiev of Sociology / Revue Internationale de Sociologie, 14(3), 484-501.

Karalar, R. (2001). Genel işletme. Eskişehir: AÖF Yayınları. 
Karalar, R., Özalp, İ., Maviş, F., Geylan, R., Tenekecioğlu, B., Şahin, M., . . . Aydın, N. (2006). Genel işletme. Eskişehir: Anadolu Üniversitesi Yayını, 6. baskı.

Kuvan, H. (2007). Türk Girişimcilerin Yaşam ve Çalışma Değerleri, Malatya'lı Girişimciler Üzerine Bir Araştırma. Yayınlanmamış Doktora Tezi, 7980. Isparta: Süleyman Demirel Üniversitesi Sosyal Bilimler Enstitüsü.

Küçük, O. (2005). Girişimcilik ve küçük işletme yönetimi. Ankara: Seçkin Yayıncllik.

Müftüoğlu, M. T. (2004). Girişimcilik. Eskişehir: AÖF Yayınları.

Müftüoğlu, M. T., ve Durukan, T. (2004). Girişimcilik ve KOBI'ler. Ankara: Gazi Yayınevi.

Müftüoğlu, T., Ürper, Y., Başar, Y., ve Tosunoğlu, M. (2005). Girişimcilik. Eskişehir: Anadolu Üniversitesi Yayını No:1567 2.baskı.

Odabaşı, Y. (2005). Değişim ve Dönüşümün Aracı Olarak Girişimci Üniversite. Akdeniz Üniversitesi "Üniversitelerde Strateji Planlama Paneli" (s. 91). Anadolu Üniversitesi İşletme Fakültesi.

Özakpınar, Y. (1999). Kültür değişmeler ve batılllaşma meselesi. İstanbul: Ötüken Yayınları.

Perktaş, E. (2014). Bölgesel kalkınma özelinde girişimciliğin ekonomik kalkınma sürecindeki rolü. Akademik Sosyal Araştırmalar Dergisi(7), 472486.

Santarelli, E., ve Vivarelli, M. (2007). Enrepreneurship and the process of firms 'entry, survival and growth'. Industrial and Corporate Change Journal, 16(3), 455-488.

Savaş, V. (2007). İktisadın tarihi. Ankara: Siyasal Kitabevi, 5.bask1.

Schumpeter, J. A. (1942). Capitalism, socialism, and democracy. New York: Harber and Brothers.

Schumpeter, J. A. (1961). The theory of economic development; an inquiry into profits, capital, credit, interest and the business cycle . Oxford University Press, 7(3), 87-94.

Schumpeter, J. A., ve Takata, Y. (1998). Power or pure economics? (M. Morishima, Dü.) London: MacMillan Press.

Sciascia, S., ve Vita, R. D. (2004). The development of entrepreneurship research. Liuc Papers n.146.

Süzer, D. H. (2005). Müşteri yönetiminde on öldürücü hata. http://www.capital.com.tr/. adresinden 05.03.2019 tarihinde erişilmiştir. 
Taymaz, E. (2001). Ulusal yenilik sistemi: Türkiye imalat sanayinde teknolojik değişim ve yenilik süreçleri. TÜBİTAK, Ankara, 3-10.

Tekin, M., ve Çiçek, E. (2005). Bilgi Çă̆ında Bilgi Toplumu ve Bilgi Ekonomisi. http://www.bilgiyonetimi.org/cm/pages/mkl/_gos.php?nt=149_-ftn 17. adresinden 05.03.2019 tarihinde erişilmiştir.

Timmons, J. A. (1999). New venture creation: Entrepreneurship for the 21st century. (Fifth Edition b.). United States: The Mcgraw-Hill Book Co.

Tiryakioğlu, M. (2009). Schumpeter, yenilik ve yaratıcı yıkım. İktisadiyat: http://www.iktisadiyat.com/2009/03/18/schumpeter-yenilik-ve-yaratici-yikim/ adresinden 06.03.2019 tarihinde erişilmiştir.

Titiz, T. (1994). Girişimcilik. Ankara: İnkılap Kitabevi.

Ülgener, S. F. (2013, Aralık 24). Joseph A. Schumpeter. İktisat Akademisi:https://akademikokumalar.wordpress.com/2013/12/24/joseph-aschumpeter-1883-1950/ adresinden 03.03.2019 tarihinde erişilmiştir.

Üzülmez, H. (2008). Girişimcilik ve Konya'da girişimciliğ̈in gelişimi. Girişimcilik ve Kalkınma Dergisi, 3(2), 21.

Vural, S. (2006). Girişimci kişilik özellikleri ve biga ilçesi girişimcilik profili araştırması. Dönem Projesi, 42. Çanakkale OnSekiz Mart Üniversitesi.

Whelan, G., ve O'Gorman, C. (2007). The Schumpeterian and universal hero myth in stories of Irish entrepreneurs. Irish Journal of Management, 28(2), 79-107.

Yelkikalan, N., Akatay, A., ve Altın, E. (2010). Yeni girişimcilik modeli ve yeni nesil girişimci profili; internet girişimciliği ve $Y, M, Z$ kuşağ 1 girişimci. SÜ İ̈BF Sosyal ve Ekonomik Araştırmalar Dergisi, 10(20), 491-511.

Yeniçeri, Ö. (2002). örgütleri etkinleştirme aracı olarak bilgi ve bilgi yönetimi. 2023 Dergisi 2(3),57-65.

\section{Kaynakça Bilgisi / Citation Information}

Öz, S., Dindarik, N. ve Duman, F. (2019). Schumpeteryan girişimcilik ve 21. yüzyıl girişimcilik yaklaşımları: $Y$ kuşağı girişimcileri üzerine nitel bir araştırma. OPUS-Uluslararası Toplum Araştırmaları Dergisi, 13(19), 1056-1091. DOI: 10.26466/opus.568703. 